\title{
PENENTUAN RUTE DISTRIBUSI PRODUK KAOS PADA DOBUJACK INV. MENGGUNAKAN METODE NEAREST NEIGHBOUR DAN (1-0) INSERTION INTRA ROUTE
}

\section{ROUTING PROBLEM USED NEAREST NEIGHBOUR METHOD AND (1-0) INSERTION INTRA ROUTE AT DOBUJACK INV.}

\author{
${ }^{1}$ Handi Koswara, ${ }^{2}$ Hari Adianto, ${ }^{3}$ Andrian Nugraha \\ 1,2,3 Program Studi Teknik Industri, Fakultas Teknologi Industri, Institut Teknologi Nasional, Bandung \\ 'handi.koswara@itenas.ac.id,'hari@itenas.ac.id, ${ }^{3}$ andrianugr@gmail.com.
}

\begin{abstract}
Abstrak- Makalah ini membahas pemecahan permasalah pengiriman pada Dobujack Inv. Rute pengiriman kaos pada tiap pelanggan saat ini dilakukan oleh intuisi dari supir, maka dari itu efisiensi pengiriman tidak tercapai karena jarak serta waktu yang tidak pasti. Permasalahan penentuan rute tersebut termasuk dalam permasalahan Vehicle Routing Problem (VRP). VRP tersebut adalah permasalahan penentuan rute pada pengiriman yang berpusat pada satu atau lebih depot dengan pelanggan yang tersebar serta permintaan yang berbeda-beda. Permasalahan VRP ini diselesaikan dengan menggunakan metode nearest neighbour pada awal pembentukan rute, selanjutnya di optimasi dengan menggunakan metode (1-0) Insertion Intra Route. Hasil penelitian ini menghasilkan tur dengan penghematan jarak dan waktu dalam melakukan pendistribusian untuk perusahaan.
\end{abstract}

Kata kunci: Vehicle Routing Problem, Nearest Neighbour, (1-0) Insertion Intra Route

\begin{abstract}
This paper discusses how to solve shipping problems on Dobujack Inv. The delivery route of clothes for each customer is done by driver of the intuition, so the delivery efficiency is not achieved due to the distance and the uncertain time. The route problem is called Vehicle Routing Problem (VRP). VRP is a route problem that focusing on one depot among customer. VRP can be solved by using nearest neighbour method at the beginning furthermore, it should've be optimized with (1-0) Insertion Intra Route method. This study resulted in a tour with the savings of distance and time in the distribution for the company.
\end{abstract}

Keywords: Vehicle Routing Problem, Nearest Neighbour, (1-0) Insertion Intra Route

\section{PENDAHULUAN}

Distro dan Konveksi Dobujack Inv. sebagai perusahaan yang memproduksi pakaian serta pelanggan yang cukup banyak tentu perlu untuk penentuan rute pengiriman yang tepat karena saat ini

$\begin{array}{ll}\text { Sejarah artikel } & \\ \text { Diterima redaksi: } & : \text { 05 Desember } 2017 \\ \text { Revisi akhir } & : \text { 17 Desember } 2017 \\ \text { Diterbitkan online } & : \text { 29 Desember } 2017\end{array}$

perusahaan belum mempunyai penentuan rute yang pasti. Penentuan rute yang tepat tentu akan mengurangi biaya yang dikeluarkan saat pendistribusian sehingga menghasilkan profit yang lebih besar. Masalah seperti itu dikarenakan banyaknya titik tujuan pendistribusian dan perusahaan belum mempunyai rute pendistribusian yang tetap atau berubah-ubah, sehingga perusahaan membutuhkan suatu cara untuk menyelesaikan permasalahan pendistribusian tersebut.

Permasalahan seperti ini biasa disebut dengan Vehicle Routing Problem (VRP). VRP akan menghasilkan rute yang minimum serta mempertimbangan kapasitas kendaraan. Untuk mengatasi masalah tersebut dapat diselesaikan dengan berbagai macam metode yaitu nearest neighbour dan (1-0) insertion intra route. Metode nearest neighbour yaitu metode dengan menggabungkan 2 tempat atau lebih kedalam satu rute agar menghasilkan waktu penyelesaian serta solusi yang optimal. Sedangkan metode (1-0) insertion intra route merupakan proses perbaikan dilakukan dengan memindahkan satu titik ke titik pelanggan lain dalam suatu rute yang sama.

\section{A. Identifikasi Masalah}

Distro dan Konveksi Dobujack Inv. adalah perusahaan yang membuat produk pakaian. Perusahaan berdiri pada tahun 2005, saat awal berdiri perusahaan hanya membuat baju dengan jaket, namun seiring perkembangan zaman perusahaan semakin banyak membuat varian produknya. Untuk saat ini perusahaan belum mempunyai penentuan rute yang tetap dalam setiap pengiriman produknya, sehingga supir tidak mengetahui mana tempat yang harus dituju terlebih dahulu, maka dari itu penentuan rute dapat meningkatkan efektifitas dan efisiensi dalam pendistribusian.

Selama ini proses pengiriman produk tersebut dilakukan mengandalkan pengalaman dari supir. Tentu saja dengan menggunakan hanya pengalaman pasti setiap pengiriman akan menghasilkan waktu yang lama serta jarak yang jauh karena dilakukan tanpa perhitungan. Permasalahan seperti ini biasa disebut dengan Vehicle Routing Problem (VRP). Untuk mengatasi masalah 
tersebut dapat diselesaikan dengan berbagai macam metode yaitu nearest neighbour dan (1-0) insertion intra route.

\section{STUDILITERATUR}

\section{A. Supply Chain dan Supply Chain Management}

Supply chain adalah jaringan perusahaan-perusahaan yang secara bersama bekerja untuk menciptakan dan menghantarkan suatu produk ke pemakai akhir. Perusahaan tersebut biasanya adalah supplier, pabrik, distributor, serta perusahaan pendukung lainnya seperti jasa logistik [8]. Supply Chain Management adalah pengelolaan kegiatan dalam rangka memperoleh bahan mentah menjadi barang dalam proses atau barang setengah jadi dan barang jadi kemudian mengirimkan produk tersebut ke konsumen melalui sistem distribusi. Kegiatan-kegiatan ini mencangkup fungsi pembelian tradisional ditambah kegiatan penting lainnya yang berhubungan antara pemasok dengan distributor [5]. Adapun kegiatan-kegiatan utama yang masuk dalam klasifikasi SCM yaitu:

1. Kegiatan merancang produk baru (Product Development).

2. Kegiatan mendapatkan bahan baku (Procurement, Purchasing atau Supply).

3. Kegiatan merencanakan produk dan persediaan (Planning \& Control)

4. Kegiatan melakukan produksi (Production).

5. Kegiatan melakukan distribusi atau pengiriman (Distribution).

6. Kegiatan pengelolaan pengembalian produk (Return).

\section{B. Distribusi dan Transportasi}

Distribusi maupun transportasi memungkinkan perpindahan produk dari lokasi di produksi ke lokasi konsumen atau pemakai yang dibatasi oleh jarak [8]. Adapun strategi yang dilakukan dalam melakukan distribusi yaitu Pengiriman Langsung (Direct Shipment), Pengiriman Melalui Warehouse, dan Cross-Docking. Transportasi berperan penting dalam manajemen rantai pasok. Dalam konteks rantai pasok, transportasi berperan penting karena sangatlah jarang suatu produk diproduksi dan dikonsumsi dalam satu lokasi yang sama. Strategi rantai pasok yang diimplementasikan dengan sukses memerlukan pengelolaan transportasi yang tepat.

\section{Vehicle Routing Problem(VRP)}

Vehicle routing problem (VRP) adalah permasalahan pengiriman atau distribusi yang melibatkan sekumpulan rute kendaraan yang berpusat pada satu depot atau lebih untuk melayani pelanggan yang tersebar di berbagai wilayah sesuai permintaan masing-masing [6]. Tujuan dari VRP adalah untuk mendapatkan rute terpendek dan dengan rute yang pendek perusahaan akan menghasilkan profit yang lebih besar. Suprayogi (2003) memberikan beberapa contoh variasi dari VRP yaitu:

1. VRP Time Windows (VRPTW)

Setiap pelanggan memiliki rentang waktu dalam pelayanan, pelayanan harus dilakukan pada rentang waktu atau time windows masing-masing pelanggan.

2. VRP Split Delivery (VRPSD)

Pelanggan dapat dilayani lebih dari satu kendaraan, hal ini biasanya terjadi karena terbatasnya kapasitas kendaraan dalam melayani pelanggan.
3. VRP PickUp and Delivery (VRPPD)

Kendaraan melakukan dua tugas sekaligus, yaitu melakukan pengambilan dan pengantaran produk pada pelanggan.

4. VRP Multiple Depots (VRPMD)

VRP ini memiliki depot lebih dari satu.

5. VRP Multiple Products (VRPMP)

Karakteristik VRP ini adalah permintaan pelanggan lebih dari satu produk.

6. VRP Multiple Trips (VRPMT)

Karakteristik dari VRP ini adalah satu kendaraan dapat menempuh beberapa rute untuk memenuhi kebutuhan pelanggan.

7. VRP Heterogeneous Fleet of Vehicles (VRPHFV)

Kendaraan yang digunakan bermacam-macam dengan karakteristik yang berbeda-beda.

8. Periodic VRP (PVRP)

Dalam VRP standar, horison perencanaan hanya berlaku pada satu hari, pada variasi VRP ini pelayanan kepada pelanggan dapat dilakukan dalam beberapa waktu selama horison perencanaan.

9. Stochastic VRP (SVRP)

Parameter angka (seperti jumlah pelanggan, permintaan masing-masing pelanggan, dan waktu layanan) bersifat acak atau tidak pasti, setiap pelanggan memiliki kemungkinan untuk tidak dikunjungi setiap hari.

10. Dynamic VRP (DVRP)

VRP jenis ini bertujuan untuk mengantisipasi apabila terdapat pelanggan baru pada rute tertentu, pelanggan baru ini harus disisipkan pada rute tambahan saat pembuatan rute pengiriman utama.

\section{NearestNeighbour}

Metode nearest neighbour prinsipnya adalah menambahkan toko yang jaraknya paling dekat dengan toko yang dikunjungi terakhir [8]. Metode nearest neighbour dilakukan dengan mencari konsumen terdekat dengan depot lalu konsumen tersebut menjadi titik awal serta selanjutnya mencari jarak paling dekat dari konsumen tersebut dan berlanjut terus menerus. Adapun langkah-langkah yang digunakan dalam menggunakan metode ini:

1. Memilih titik pusat menjadi titik awal dalam pengiriman.

2. Menentukan tujuan dengan jarak terpendek dari gudang, dan melakukan penggabungan rute.

3. Titik terakhir yang telah dikunjungi menjadi titik awal, dan cari titik yang terpendek dari titik terakhir dikunjungi.

4. Lakukan pengulangan sampai kapasitas kendaraan tidak mencukupi.

5. Titik ini dinamakan dengan satu rute perjalanan, kapasitas kendaraan yang menjadi kendala dalam pengiriman.

6. Lakukan proses yang sama yaitu dengan melakukan langkah kesatu sampai langkah kelima.

\section{E. Local Search (1-0) Insertion Intra Route}

Algoritma local search didefinisikan sebagai metode mataheuristik yang menggunakan beberapa kombinasi dari teknik optimasi [13]. Proses perbaikan dilakukan dengan memindahkan satu titik ke titik pelanggan lain dalam suatu rute yang sama. Insertion 
intra-route (1-0) merupakan proses memindahkan konsumen dengan konsumen lainnya secara berurutan yang dilakukan pada rute yang sama dengan tujuan untuk meminimasi waktu yang diperlukan untuk melakukan pendistribusian setiap operatornya. Proses penukaran terus dilakukan dengan membandingkan keseluruhan hasil penukaran (Best Solution) atau proses penukaran berhenti ketika mendapatkan solusi yang baik dengan total jarak sesudah penukaran lebih kecil dibandingkan total jarak sebelum dilakukan penukaran (First Best Solution).

\section{METODOLOGI PENELITIAN}

A. Penentuan Rute Awal Menggunakan Metode Nearest Neighbour

Penentuan rute pendistribusian awal menggunakan metode nearest neighbour bertujuan untuk melakukan pendistribusian dari satu titik ke titik yang lain serta mencari jarak terdekat dari setiap titik tersebut. Langkah-langkah yang dapat dilakukan dalam penyelesaian dapat dilihat dibawah ini:

\section{Langkah 1}

Input data permintaan setiap pelanggan (Di), Jarak antara depot ke pelanggan dan pelanggan ke pelanggan, Horison perencanaan $(\mathrm{H})$, Waktu loading (LT) dan unloading (UT). Lanjutkan ke langkah 2.

\section{Langkah 2}

Inisialisasi awal, rute $(\mathrm{r}=1)$ dan tur $(\mathrm{t}=1)$. Lanjutkan ke langkah 3.

\section{Langkah 3}

Lokasi awal dari depot. Lanjutkan ke langkah 4

\section{Langkah 4}

Cari pelanggan yang memiliki jarak terpendek dari lokasi terakhir, lanjut ke langkah 5.

\section{Langkah 5}

Hitung waktu tempuh perjalanan antar lokasi (WT), lanjutkan ke langkah 6.

\section{Langkah 6}

Hitung Waktu Unloading time (UT), atau waktu penurunan produk ke tiap toko. Lanjutkan ke langkah 7.

\section{Langkah 7}

Hitung waktu administrasi (Wadm), Lanjutkan ke langkah 8.

\section{Langkah 8}

Hitung waktu penyelesaian (CT), dengan perhitungan dibawah ini:

$C T_{i}=C T_{i-1}+\mathrm{WT}+\mathrm{UT}+\mathrm{LT}+\mathrm{Wadm}$

- Jika waktu penyelesaian $\left(C T_{i}\right) \leq$ Jam Kerja maka Lanjut ke langkah 10

- $\quad$ Jika waktu penyelesaian $\left(C T_{i}\right) \geq$ Jam Kerja maka kembali ke depot pendistribusian selesai.

\section{Langkah 9}

- Apabila semua pelanggan sudah terlayani pendistrbusian selesai.

- Apabila masih ada pelanggan belum terlayani dan kapasitas mobil > 0, lanjut ke langkah 10.

- Jika Kapasitas Mobil < 0, Lanjutkan ke langkah 11 .

\section{Langkah 10}

Titik terakhir pelanggan menjadi titik awal untuk pengiriman, serta cari jarak yang paling dekat. Lanjutkan ke langkah 12.

\section{Langkah 11}

Kembali ke depot serta menghitung waktu tempuh saat perjalanan. Lanjutkan langkah 4.

\section{Langkah 12}

- Jika waktu penyelesaian $\left(C T_{i}\right) \leq$ Jam Kerja maka Lanjut ke langkah 4.

- $\quad$ Jika waktu penyelesaian $\left(C T_{i}\right) \geq$ Jam Kerja maka kembali ke depot pendistribusian selesai.

Langkah 13

Lakukan seterusnya sampai semua pelanggan terpenuhi.

B. Penentuan Rute Menggunakan Metode Local Search (1-0) Insertion Intra Route

Algoritma local search adalah metode heuristik yang menggunakan beberapa kombinasi dari teknik optimasi [13]. Insertion intra-route (1-0) merupakan salah satu operator dalam local search, proses perbaikan dilakukan dengan memindahkan satu titik ke titik pelanggan lain dalam suatu rute yang sama. Adapun langkahnya sebagai berikut:

\section{Langkah 1}

Input tur dan rute hasil pembentukan metode nearest neighbour, matriks jarak, Loading Time dan Unloading Time, permintaan setiap pelanggan (Di), kapasitas kendaraan (Q). Lanjutkan ke langkah 2.

Langkah 2

Dimulai dari tur ke 1, i = 1. Lanjutkan ke langkah 3.

\section{Langkah 3}

Melakukan proses insertion intra-route (1-0), menukar urutan pelayanan setiap titik pelanggan dalam rute yang sama untuk setiap rute kendaraan, lanjutkan ke langkah 4 jika semua rute telah dicari.

\section{Langkah 4}

Jika total jarak pada rute yang baru lebih kecil dari sebelumnya maka pilih rute tersebut untuk menggantikan rute sebelumnya. Lakukan sampai pertukaran selesai dan lanjutkan ke Langkah 2. Apabila semua tur telah dilakukan pertukaran lanjutkan ke langkah 5.

\section{Langkah 5}

Prosedur selesai.

\section{HASIL DAN ANALISIS}

\section{A. Pengumpulan Data}

Pengumpulan data berisikan data-data yang dibutuhkan untuk menyelesaikan permasalahan VRP dengan menggunakan Nearest Neighbour dan insertion intra-route (1-0). Data yang dibutuhkan dapat dilihat dibawah ini:

1. Data Jarak

Data jarak berisikan jarak dari gudang ke tiap toko maupun jarak tiap toko ke toko. Saat ini perusahaan tidak mempunyai jarak tempuh tersebut, maka dari itu menggunakan bantuan google maps.

2. Data Waktu

Data waktu merupakan waktu yang dibutuhkan saat perjalanan pendistribusian dari toko ke toko lainnya. Data tersebut merupakan hasil bantuan dari google maps. 
3. Kecepatan Kendaraan

Kecepatan kendaraan rata-rata adalah $30 \mathrm{~km} / \mathrm{jam}$ untuk didalam Kota, sedangkan untuk luar Kota (Jalan Tol) adalah $40 \mathrm{~km} / \mathrm{jam}$ yang diambil dari wawancara terhadap supir. Kecepatan rata-rata tersebut telah memperhitungkan kemacetan.

4. Kapasitas Kendaraan

Kendaraan yang digunakan oleh perusahaan adalah jenis mobil minibus. Kapasitas dari mobil tersebut merupakan hasil dari wawancara. Kapasitas dari mobil minibus tersebut adalah 125 lusin.

5. Waktu Tempuh

Waktu tempuh adalah waktu yang dihitung atau waktu perjalanan dari gudang ke toko 1 maupun ke toko yang lainnya. Perhitungan waktu tempuh didapatkan dari jarak tempuh dibagi kecepatan kendaraan yang selanjutnya dikalikan dengan 60 atau dengan satuan menit per-jam. Lebih lengkapnya dapat dilihat dibawah ini:

$W T=\frac{\text { Jarak Antar Toko dan Gudang }(\mathrm{Km})}{\text { Kecepatan Kendaraan rata }-\operatorname{rata}(\mathrm{Km} / \mathrm{Jam})} \times 60$

6. Waktu Loading dan Unloading

Waktu Loading dan Unloading didapatkan berdasarkan hasil wawancara. Waktu loading adalah waktu yang dibutuhkan saat pengangkatan karung dari gudang kedalam mobil. Waktu yang dibutuhkan untuk pengisian produk kedalam mobil sekitar 30 menit. Sedangkan waktu unloading adalah sekitar 1 menit untuk tiap lusin.

7. Jam Kerja Supir

Jam kerja supir adalah waktu yang dihabiskan oleh supir saat melakukan pendistribusian kaos saat ke tiap toko. Jam kerja supir adalah 8 jam kerja

8. Waktu Administrasi

Waktu pelayanan administrasi adalah waktu yang dibutuhkan ketika melakukan administrasi pada tiap toko. Biasanya hal yang dilakukan ketika melakukan administrasi adalah tanda tangan serah terima barang serta pengecekan kelengkapan jumlah produk. Waktu administrasi membutuhkan waktu 5 menit yang merupakan hasil wawancara pada supir.

B. Pembentukan Rute Menggunakan Metode Nearest Neighbour Penentuan rute pendistribusian awal menggunakan metode nearest neighbour

\section{Langkah 1}

Input data permintaan setiap pelanggan $(\mathrm{Di})=0$, horison perencanaan $(\mathrm{H})=480$ Menit, Kapasitas Kendaraan $(\mathrm{Q})=125$ Lusin, Waktu loading (LT) = 30 Menit, dan unloading (UT) = 1 Menit/Lusin. Lanjutkan ke langkah 2.

\section{Langkah 2}

Inisialisasi awal, rute $(\mathrm{r}=1)$ dan tur $(\mathrm{t}=1)$. Lanjutkan ke langkah 3.

\section{Langkah 3}

Lokasi awal dari depot. Melakukan loading $(\mathrm{LT})=30$ Menit, yaitu mengisi kaos kedalam mobil sebanyak 125 Lusin. Tur 1 Rute 1 dapat dilihat pada Tabel I.

\section{Langkah 4}

Pelanggan yang memiliki jarak terpendek dari lokasi terakhir adalah P40, yaitu Jl. Sukanegara No. 55 Antapani Bandung dengan Jarak 1,4 Km.

\section{Langkah 5}

Waktu tempuh dari depot ke P40 adalah 2,6 menit.

\section{Langkah 6}

Waktu Unloading time (UT) yang dibutuhkan saat melakukan penurunan barang ke lokasi adalah $U T=8$ menit.

TABEL I

RUTE AWAL TUR 1 RUTE 1

Tur Rute

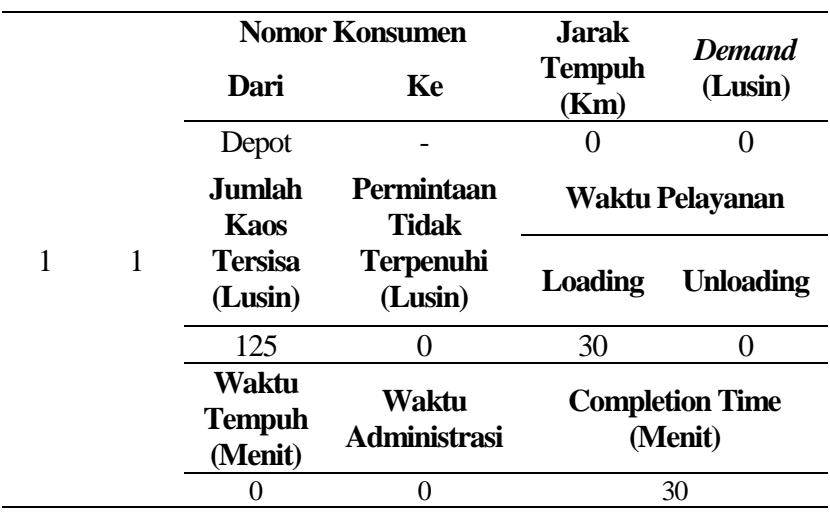

\section{Langkah 7}

Waktu administrasi (Wadm) yang dibutuhkan adalah 5 menit tiap toko, Waktu administrasi biasanya melakukan serah terima barang serta pengecekan kelengkapan jumlah pesanan.

Langkah 8

Perhitungan waktu penyelesaian (CT) dapat dilihat dibawah ini pada Tabel II.

$$
\begin{aligned}
& C T_{i}=C T_{i-1}+\mathrm{WT}+\mathrm{UT}+\mathrm{LT}+\mathrm{Wadm} \\
& C T_{i}=30+2,6+8+0+5 \\
& C T_{i}=45,600 \text { Menit }
\end{aligned}
$$

Waktu penyelesaian $\left(C T_{i}\right) \leq$ Jam Kerja atau 45,600 $\leq 480$.

Maka dari itu lanjut ke langkah selanjutnya.

\section{Langkah 9}

Kapasitas Mobil > 0, atau Q saat ini adalah 118 Lusin. Maka dari itu Lanjutkan ke langkah 10.

\section{Langkah 10}

Titik terakhir pelanggan menjadi titik awal untuk pengiriman, atau P40 menjadi titik awal serta lokasi terdekat berdasarkan matriks jarak dengan P40 adalah P27. Lanjut ke langkah 5.

\section{Langkah 5}

Waktu tempuh dari P40 ke P27 dapat dilihat dibawah ini

$$
\begin{aligned}
& \mathrm{WT}=\frac{\text { Jarak Antar Toko dan Gudang }(\mathrm{Km})}{30} \times 60 \\
& \mathrm{WT}=\frac{0,8}{30} \times 60 \\
& \mathrm{WT}=1,6 \text { Menit }
\end{aligned}
$$

\section{Langkah 6}

Waktu Unloading time (UT) yang dibutuhkan saat melakukan penurunan barang ke lokasi dapat dilihat dibawah ini: 


\section{Langkah 7}

$$
\begin{aligned}
& \text { UT }=\text { Jumlah Lusin Kaos x } 1 \text { Menit } \\
& \text { UT }=8 \text { Lusin Kaos x } 1 \text { Menit } \\
& \text { UT }=8 \text { Menit }
\end{aligned}
$$

Waktu administrasi (Wadm) yang dibutuhkan adalah 5 menit tiap toko, Waktu administrasi biasanya melakukan serah terima barang serta pengecekan kelengkapan jumlah pesanan.

TABEL II

\begin{tabular}{|c|c|c|c|c|c|}
\hline & & Nomol & Konsumen & Jarak & Domand \\
\hline & & Dari & $\mathbf{K e}$ & $\begin{array}{c}\text { Tempuh } \\
(\mathbf{K m})\end{array}$ & (Lusin) \\
\hline & & Depot & $\mathrm{P} 40$ & 1,3 & 8 \\
\hline & & $\begin{array}{l}\text { Jumlah } \\
\text { Kaos }\end{array}$ & $\begin{array}{l}\text { Permintaan } \\
\text { Tidak }\end{array}$ & Waktu & elayanan \\
\hline 1 & 1 & $\begin{array}{l}\text { Tersisa } \\
\text { (Lusin) }\end{array}$ & $\begin{array}{c}\text { Terpenuhi } \\
\text { (Lusin) }\end{array}$ & Loading & Unloading \\
\hline & & 117 & 0 & 0 & 8 \\
\hline & & $\begin{array}{l}\text { Waktu } \\
\text { Tempuh } \\
\text { (Menit) }\end{array}$ & $\begin{array}{c}\text { Waktu } \\
\text { Administrasi }\end{array}$ & $\begin{array}{r}\text { Comple } \\
\text { (M }\end{array}$ & $\begin{array}{l}\text { ion Time } \\
\text { nit) }\end{array}$ \\
\hline & & 2,6 & 5 & & 8 \\
\hline
\end{tabular}

RUTE AWAL TUR 1 RUTE 1 KONSUMEN 1

\section{Tur Rute}

\section{Langkah 8}

Perhitungan waktu penyelesaian (CT) dapat dilihat dibawah ini pada Tabel IIII.

\begin{tabular}{|c|c|c|c|c|c|}
\hline \multirow{8}{*}{1} & \multirow{8}{*}{1} & \multicolumn{2}{|c|}{ Nomor Konsumen } & \multirow{2}{*}{$\begin{array}{c}\text { Jarak } \\
\text { Tempuh } \\
\text { (Km) }\end{array}$} & \multirow{2}{*}{$\begin{array}{c}\text { Demand } \\
\text { (Lusin) }\end{array}$} \\
\hline & & Dari & $\mathbf{K e}$ & & \\
\hline & & $\mathrm{P} 40$ & $\mathrm{P} 27$ & 0,8 & 8 \\
\hline & & $\begin{array}{c}\text { Jumlah } \\
\text { Kaos }\end{array}$ & $\begin{array}{l}\text { Permintaan } \\
\text { Tidak }\end{array}$ & \multicolumn{2}{|c|}{ Waktu Pelayanan } \\
\hline & & $\begin{array}{l}\text { Tersisa } \\
\text { (Lusin) }\end{array}$ & $\begin{array}{c}\text { Terpenuhi } \\
\text { (Lusin) }\end{array}$ & Loading & Unloading \\
\hline & & 109 & 0 & 0 & 9 \\
\hline & & $\begin{array}{l}\text { Waktu } \\
\text { Tempuh } \\
\text { (Menit) }\end{array}$ & $\begin{array}{c}\text { Waktu } \\
\text { Administrasi }\end{array}$ & \multicolumn{2}{|c|}{$\begin{array}{l}\text { Completion Time } \\
\text { (Menit) }\end{array}$} \\
\hline & & 1,6 & 5 & \multicolumn{2}{|c|}{60,2} \\
\hline
\end{tabular}

$$
\begin{gathered}
C T_{i}=C T_{i-1}+\mathrm{WT}+\mathrm{UT}+\mathrm{LT}+\mathrm{Wadm} \\
C T_{i}=45,600+1,6+8+0+5 \\
C T_{i}=60,200 \text { Menit } \\
\text { TABEL III } \\
\text { RUTE AWAL TUR 1 RUTE 1 KONSUMEN2 }
\end{gathered}
$$

Tur Rute

Waktu penyelesaian $\left(C T_{i}\right) \leq$ Jam Kerja atau 60,200 $\leq 480$. Maka dari itu lanjut ke langkah selanjutnya.

Langkah 9

Kapasitas Mobil > 0, atau Q saat ini adalah 109 Lusin. Maka dari itu Lanjutkan ke langkah 10.

\section{Langkah 10}

Titik terakhir pelanggan menjadi titik awal untuk pengiriman, atau P27 menjadi titik awal serta lokasi terdekat berdasarkan matriks jarak dengan P27 adalah P28. Lanjut ke langkah 11.

\section{Langkah 11}

Kembali ke depot serta menghitung waktu tempuh saat perjalanan.

\section{Langkah 12}

- Jika waktu penyelesaian $\left(C T_{i}\right) \leq$ Jam Kerja maka Lanjut ke langkah 4.

- $\quad$ Jika waktu penyelesaian $\left(C T_{i}\right) \geq$ Jam Kerja maka kembali ke depot pendistribusian selesai.

\section{Langkah 13}

Lakukan seterusnya seperti langkah diatas sampai semua pelanggan terpenuhi. Pembentukan rute dengan menggunakan metode Nearest Neighbour dapat dilihat pada Tabel IV.

TABEL IV

HASIL PEMBENTUKAN RUTE MENGGUNAKAN NEAREST NEIGHBOUR

\begin{tabular}{ccc}
\hline Tur & Rute & Urutan Konsumen yang Dilayani \\
\hline \multirow{2}{*}{1} & 1 & 0-P40-P27-P28-P32-P33-P36-P21-P14-P22-0 \\
& 2 & 0-P39-P30-P37-P18-P19-P1-0 \\
2 & 1 & 0-P26-P3-P31-P24-P25-P41-P16-P29-0 \\
3 & 2 & 0-P29-P34-P35-0 \\
4 & 1 & 0-P17-P15-P23-P38-P20-0 \\
\hline
\end{tabular}

C. Perbaikan Rute dengan Menggunakan Metode (1-0) Insertion Intra Route

\section{Langkah 1}

Input tur dan rute menggunakan data dari perhitungan hasil metode nearest neighbour. Lanjutkan ke langkah 2.

Langkah 2

Dimulai dari tur ke $1, \mathrm{i}=1$. Total jarak dari pembentukan Tur serta Rute menggunakan perhitungan Nearest Neighbour dapat dilihat pada Tabel V.

TABEL V

TOTAL JARAK PEMBENTUKAN TUR 1 RUTE 1 MENGGUNAKAN NEAREST NEIGHBOUR

\begin{tabular}{ccc}
\hline \multicolumn{2}{l}{ Nomor Konsumen } & Jarak Tempuh $(\mathrm{Km})$ \\
Dari & Ke & 0 \\
\hline Depot & - & 1,3 \\
Depot & P40 & 0,8 \\
P40 & P27 & 1,6 \\
P27 & P28 & 2,5 \\
P28 & P32 & 1,6 \\
P32 & P33 & 1,9 \\
P33 & P36 & 3,1 \\
P36 & P21 & 4,3 \\
P21 & P14 & 5,6 \\
P14 & P22 & 10,2 \\
P22 & Depot & 32,9 \\
\hline \multicolumn{3}{c}{ Total } \\
\hline
\end{tabular}

\section{Langkah 3}

Melakukan proses (1-0) insertion intra route menukar urutan pelayanan setiap titik pelanggan dalam rute yang sama untuk setiap rute kendaraan. Pertukaran dilakukan dari pelanggan 22 dengan pelanggan 14 . Hasil dari pertukaran ke-1 mendapatkan 
total jarak tempuh sebesar 30,4 Km. Dapat dilihat pada Tabel VI.

TABEL VI

PERTUKARAN KE-1 TUR 1 RUTE

\begin{tabular}{ccc}
\multicolumn{3}{c}{ PERTUKARAN KE-1 TUR 1 RUTE 1 } \\
\hline \multicolumn{2}{c}{ Nomor Konsumen } & Jarak Tempuh $(\mathrm{Km})$ \\
Dari & Ke & 0 \\
Depot & - & 1,3 \\
Depot & P40 & 0,8 \\
P40 & P27 & 1,6 \\
P27 & P28 & 2,5 \\
P28 & P32 & 1,6 \\
P32 & P33 & 1,9 \\
P33 & P36 & 3,1 \\
P36 & P21 & 7,5 \\
P21 & P22 & 5,6 \\
P22 & P14 & 4,5 \\
P14 & Depot & 30,4 \\
\hline \multicolumn{3}{c}{ Total } \\
\hline
\end{tabular}

Lakukan pertukaran pada semua tur sampai mendapatkan jarak yang minimum.

\section{Langkah 4}

Hasil pertukaran pelanggan ke-1 Tur 1 Rute 1 mendapatkan hasil lebih kecil dari pembentukan tur nearest neighbour, yaitu dengan jarak 30,4 Km $<33 \mathrm{Km}$. Maka dari itu pertukaran tersebut dapat mengganti rute yang telah terbentuk dari nearest neighbour. Lakukan sampai pertukaran selesai dan lanjutkan ke Langkah 2. Apabila semua tur telah dilakukan pertukaran lanjutkan ke langkah 5.

Langkah 5

Prosedur selesai.

D. Analisis Hasil Pembentukan Rute

Analisis pembentukan rute awal pengiriman kaos dobujack adalah menggunakan metode nearest neighbour. Hasil dari pengolahan data menggunakan metode nearest neighbour mendapatkan 4 tur. Total jarak tempuh yang didapatkan dari pengolahan data adalah $628,43 \mathrm{~km}$ dan waktu penyelesaian sebesar 2007,98 menit. Hasil dari pengolahan data total jarak tempuh dan waktu penyelesaian dapat dilihat pada Tabel VII.

TABEL VII

PEMBENTUKAN RUTE AWAL MENGGUNAKAN METODE NEAREST NEIGHBOUR

\begin{tabular}{ccc}
\hline Tur & Rute & Urutan Konsumen yang Dilayani \\
\hline \multirow{2}{*}{1} & 1 & 0-P40-P27-P28-P32-P33-P36-P21-P14-P22-0 \\
& 2 & 0-P39-P30-P37-P18-P19-P1-0 \\
2 & 1 & 0-P26-P3-P31-P24-P25-P41-P16-P29-0 \\
3 & 2 & 0-P29-P34-P35-0 \\
4 & 1 & 0-P17-P15-P23-P38-P20-0 \\
\hline Jarak Tempuh (Km) & Waktu Penyelesaian (Menit) \\
\hline \multicolumn{4}{c}{ 0.P6-P13-P8-P10-P9-P11-P4-P12-P5-P7-P2-0 } \\
\multicolumn{4}{c}{32,9} & 265,8 \\
& 20,07 & 178,14 \\
& 44,6 & 289,2 \\
& 44,6 & 189,2 \\
& 82,5 & 272,0 \\
& 403,76 & 813,64 \\
\hline
\end{tabular}

Total jarak tempuh dan waktu penyelesaian pada Tabel VII adalah 628,43 km dan 2007,98 menit. Hasil dari perbaikan pembentukan rute menggunakan metode (1-0) insertion intra route hanya mendapatkan jarak yang lebih minimum pada tur 1 rute 1 , tur 1 rute 2 dan tur 4 rute 1 . Untuk tiap rute yang lainnya mendapatkan jarak tempuh yang lebih besar dibandingkan dengan pementukan rute awal. Hasil waktu penyelesaian atau completion time (CT) dari perbaikan rute mendapatkan nilai sebesar 1997,930 menit. Perbaikan rute mendapatkan total waktu penyelesaian lebih cepat sebesar 10,05 menit. Hasil dari pengolahan data total jarak tempuh dan waktu penyelesaian dapat dilihat pada Tabel VIII.

TABEL VIII

PERBAIKAN RUTE AWAL MENGGUNAKAN METODE (1-0) INSERTION INTRA ROUTE

\begin{tabular}{ccc}
\hline Tur & Rute & Urutan Konsumen yang Dilayani \\
\hline \multirow{2}{*}{1} & 1 & 0-P40-P27-P28-P32-P33-P36-P21-P14-P22-0 \\
& 2 & 0-P18-P37-P19-P1-P30-P39-0 \\
2 & 1 & 0-P26-P3-P31-P24-P25-P41-P16-P29-0 \\
3 & 2 & 0-P29-P34-P35-0 \\
4 & 1 & 0-P17-P15-P23-P38-P20-0 \\
\hline Jarak Tempuh (Km) & Waktu Penyelesaian (Menit) \\
\hline \multicolumn{4}{c}{ Th-P12-P5-P7-P2-P4-P11-P9-P10-P8-P13-P6-0 } \\
\multicolumn{4}{c}{1} & 260,8 \\
& 19,57 & 177,14 \\
& 44,6 & 289,2 \\
& 44,6 & 189,2 \\
& 82,5 & 272,0 \\
& 401,06 & 809,69 \\
\hline
\end{tabular}

Total jarak tempuh dan waktu penyelesaian pada Tabel VIII adalah $622,73 \mathrm{~km}$ dan 1997,93 menit.

\section{E. Analisis Utilitas Kapasitas Kendaraan}

Utilitas kapasitas kendaraan serta waktu penyelesaian yang tidak melebihi 8 jam kerja menjadi kendala dalam melakukan pendistribusian, Untuk saat ini dobujack inv. hanya memiliki 1 kendaraan untuk melakukan pendistribusian. Sehingga dibutuhkan waktu selama 4 hari dalam setiap pengiriman pada konsumennya. Apabila perusahaan ingin melakukan pendistribusian dengan memangkas waktu 4 hari, perusahaan dapat menambah jumlah kendaraan ataupun dengan menambah jam kerja supir. Selain itu kapasitas kendaraan juga menjadi permasalahan karena di saat kapasitas didalam kendaraan habis namun waktu penyelesaian yang masih panjang membuat mobil harus kembali ke depot dan melakukan loading kembali untuk menyelesaikan pendistribusian selanjutnya.

\section{KESIMPULAN}

Kesimpulan yang didapatkan dari hasil penelitian adalah:

1. Tur yang terbentuk dari permasalahan vehicle routing problem (VRP) dengan karakteristik VRP Multiple Trips pada perusahaan dobujack terdiri dari 4 tur dengan total keseluruhan rute sebanyak 6. Penyelesaian permasalahan VRP tersebut menggunakan metode nearest neighbour untuk pembentukan rute awal serta diperbaiki kembali dengan menggunakan metode (1-0) Insertion Intra Route.

2. Hasil perhitungan pembentukan tur awal dengan menggunakan metode nearest neighbour mendapatkan total jarak sebesar $628,43 \mathrm{Km}$ dan total jarak yang didapatkan setelah melakukan 
perbaikan dengan menggunakan metode (1-0) Insertion Intra Route mendapatkan total jarak sebesar $622,73 \mathrm{Km}$.

3. Hasil perhitungan pembentukan tur awal dengan menggunakan metode nearest neighbour mendapatkan total waktu penyelesaian atau completion time (CT) sebesar 2007,98 menit dan total waktu penyelesaian yang didapatkan setelah melakukan perbaikan dengan menggunakan metode (1-0) Insertion Intra Route mendapatkan total waktu penyelesaian sebesar 1997,930 menit. Perbaikan rute mendapatkan total waktu penyelesaian lebih cepat sebesar 10,05 menit. Perbaikan dari metode awal yang berubah adalah pada Tur 1 Rute 1 , Tur 1 Rute 2 dan Tur 4 karena menghasilkan completion time lebih sedikit dan jarak yang lebih pendek dibandingankan jarak yang didapatkan dari pembentukan tur awal.

4. Jumlah kendaraan yang dimiliki saat ini oleh dobujack inv. sebanyak 1 unit. Berarti untuk melakukan pendistribusian jika menggunakan hasil dari pembentukan tur dibutuhkan waktu selama 4 hari.

\section{DAFTAR PUSTAKA}

[1] Amin, A.R., Ikhsan, M., Wibisono, L., Traveling Salesman Problem, Jurnal Teknik Informatika, Institut Teknologi Bandung, 2012

[2] Claudya, S.H., Penentuan Rute Distribusi Es Balok Menggunakan Algoritma Nearest Neighbour dan Local Search (Studi Kasus di PT. X) ,Tugas Akhir, Jurusan Teknik Industri, Institut Teknologi Nasional, Bandung, 2014

[3] Fiantis, D., Usulan Penentuan Rute Distribusi Produk Kue Kering Menggunakan Metode Clarke \& Wright Saving Dan Branch \& Bound Di PT Bonli Cipta Sejahtera, Tugas Akhir, Jurusan Teknik Industri, Institut Teknologi Nasional, Bandung, 2017

[4] Glover, F and Laguna, M., Tabu Search, Massachusetts: Kluwer Academic Publisher, 1997

[5] Jay, H., Render, B., Operation Management $7^{\text {th }}$ Ed., Prentice Hall, New Jersey, 2005

[6] Miller, David M., Matson, Jessica O., Vaidyanathan, Bharat S., A Capacitated Vehicle Routing Problem For Just in Time delivery, ITE Trancactions, 1999

[7] Pamungkas, A.N., Pembentukan Rute Distribusi Air Mineral AlMasoem menggunakan Metode clarke \& wright savings dan nearest neighbour di PT. Al-Masoem Muawanah, Tugas Akhir, Jurusan Teknik Industri, Institut Teknologi Nasional, Bandung, 2012

[8] Pujawan, I.N., Mahendrawathi, Supply Chain Management, $2^{\text {nd }}$ ed, Guna Widya, Surabaya, 2010

[9] Pujawan, I.N., Supply Chain Management, Penerbit Guna Widya, Surabaya, 2005

[10]Satria, M.R., Rancangan Rute Distribusi Menggunakan Metode nearest neighbour, clarke \& wright savings, dan branch and bound di PT. X, Tugas Akhir, Jurusan Teknik Industri, Institut Teknologi Nasional, Bandung, 2017

[11]Suprayogi, Teknik Local Search Untuk Pemecahan Masalah Vehicle Routing Problem With Multiple Trips And Time Window. Jurnal Teknik Dan Manajemen Industri, 2007
[12]Talitha, K.R., Usulan Rancangan Rute Pendistribusian Produk Karpet Dengan Menggunakan Metode (1-0) Insertion Intra Route, Tugas Akhir, Jurusan Teknik Industri, Institut Teknologi Nasional, Bandung, 2015

[13]Toth, P. dan Vigo, D., The Vehicle Routing Problem. SIAM. Philadelphia, 2002

[14]Winarno, Algoritma Sequential Insertion Untuk Pemecahan Masalah Rute Kendaraan Heterogen Terbatas, Rute Majemuk, Pengiriman Terbagi dan Jendela Waktu. Jurnal Teknik dan Manajemen Industri, 2011 